\title{
Evolution of microstructure in an Al-Si system modified with the transition element addition and its effect on mechanicals properties.
}

\author{
H. M. Medrano-Prieto, C.G. Garay-Reyes, C.D. Gómez-Esparza, R. Martínez-Sánchez.
}

Centro de Investigación en Materiales Avanzados (CIMAV), Laboratorio Nacional de Nanotecnología, Miguel de Cervantes No. 120, C.P. 31109, Chihuahua, Chih., México.

The effect of transition element addition and solution treatment time on the microstructure and hardness of the Al-Si alloy were studied by Vickers microhardness, Rockwell B Hardness, X Ray Diffraction (XRD), Optical Microscopy (OM) and Scanning Electron Microscopy (SEM). The A319 alloy and the A319 alloys modified with Ni were solution treatment at $495{ }^{\circ} \mathrm{C}$ for 5 and 7 h, quenching in water at 60 ${ }^{\circ} \mathrm{C}$ and aged at $170{ }^{\circ} \mathrm{C}$ for $0.5,3,5,10$ and $96 \mathrm{~h}$. The $\mathrm{Ni}$ addition between 1 and 2 wt. \% to the A319 alloy have a direct effect on the microstructure, the morphology, size and distribution of precipitates during aging heat treatment, as well as, favors the formation of the $\mathrm{Al}-\mathrm{Fe}-\mathrm{Ni}, \mathrm{Al}-\mathrm{Ni}-\mathrm{Cu}-$ and $\mathrm{Al}_{3} \mathrm{Ni}_{2}$ intermetallic phases, additionally, the $\mathrm{Ni}$ presence reduce the $\mathrm{Cu}$ content in the matrix for the $\mathrm{Al}_{2} \mathrm{Cu}$ formation due formation of $\mathrm{Al}-\mathrm{Ni}-\mathrm{Cu}$ phases.

The A319 alloy is commonly used in the automotive industry as a material for engine blocks and cylinder heads. In order to improve the mechanical properties of such components they are frequently T6 heat treatment. In aluminum alloys, some transition metals like $\mathrm{Ni}$ and $\mathrm{Fe}$, and some rare earths like $\mathrm{Ce}$, which the main characteristic is their low solubility in $\mathrm{Al}$ (maximum of $0.01 \%$ to $0.03 \%$ ), are employed mainly to reduce the coefficient of thermal expansion [1]. Additionally, the Ni is commonly used in aluminum alloys to improve the mechanical properties at elevated temperatures. For example, additions of 1 to $2 \% \mathrm{Ni}$ to $2 \mathrm{xxx}$ and $3 \mathrm{xxx}$ series alloys enhance hardness and tensile properties at elevated temperatures [2-3]. Hayajneh et al. [4] studied the effect of $\mathrm{Ni}$ additions in the mechanical response in $\mathrm{Al}-\mathrm{Cu}$ alloys; they reported that the presence of the $\mathrm{Al}_{3} \mathrm{Ni}, \mathrm{Al}_{3}(\mathrm{CuNi})_{2}$ and $\mathrm{Al}_{7} \mathrm{Cu}_{4} \mathrm{Ni}$ intermetallic compounds have a direct relationship with mechanical properties. Higher amounts of dispersed intermetallic compounds higher hardness. Others investigations have reported the presence of $\mathrm{Al}_{9} \mathrm{FeNi}$ Intermetallic compound [5].

The figure 1, show the microstructure of as-cast conditions in A319 alloy modified with Ni additions, where is observed a change in morphology of dendrites and interdendritic phase (fig. 1a), as well as the presence of platelets-like phases (fig. 1b). When $\mathrm{Ni}$ is added to the Al-Si system the eutectic transformation is characterized by a simultaneous formation of eutectic $\mathrm{Si}$ and $\mathrm{Al}_{3} \mathrm{Ni}$ phase.

In figure 2, it is observed during the solution treatment as the eutectic Si platelets spheroidize and their aspect ratio decreases, which result in a loss of interconnectivity of the eutectic phases, which has been widely reported [6-7]. Additionally, the $\mathrm{Al}-\mathrm{Ni}-\mathrm{Cu}$ phases with Chinese script type and plate morphologies can be observed. 


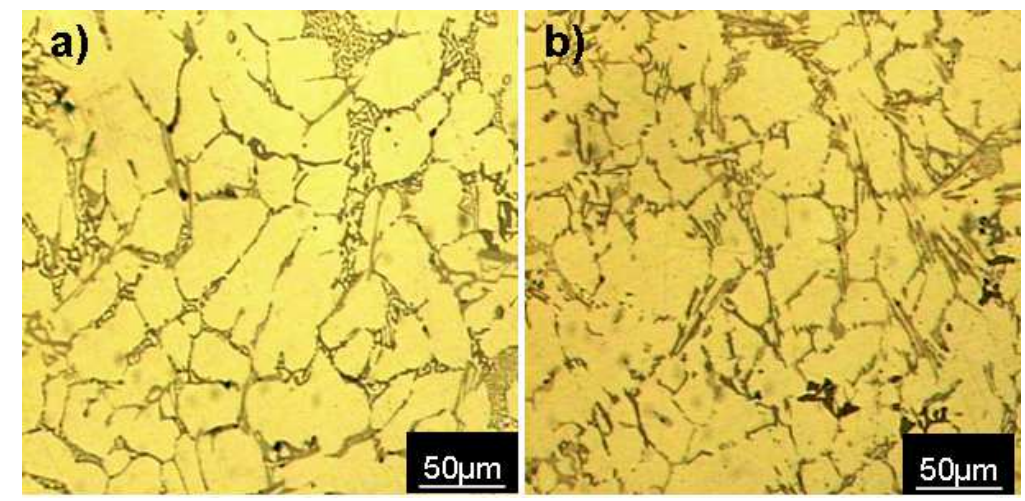

Fig. 1 OM micrographs of A319 alloy modified with Ni additions in the as-cast condition: a) 1 wt. \% Ni and b) 2 wt. \% Ni.

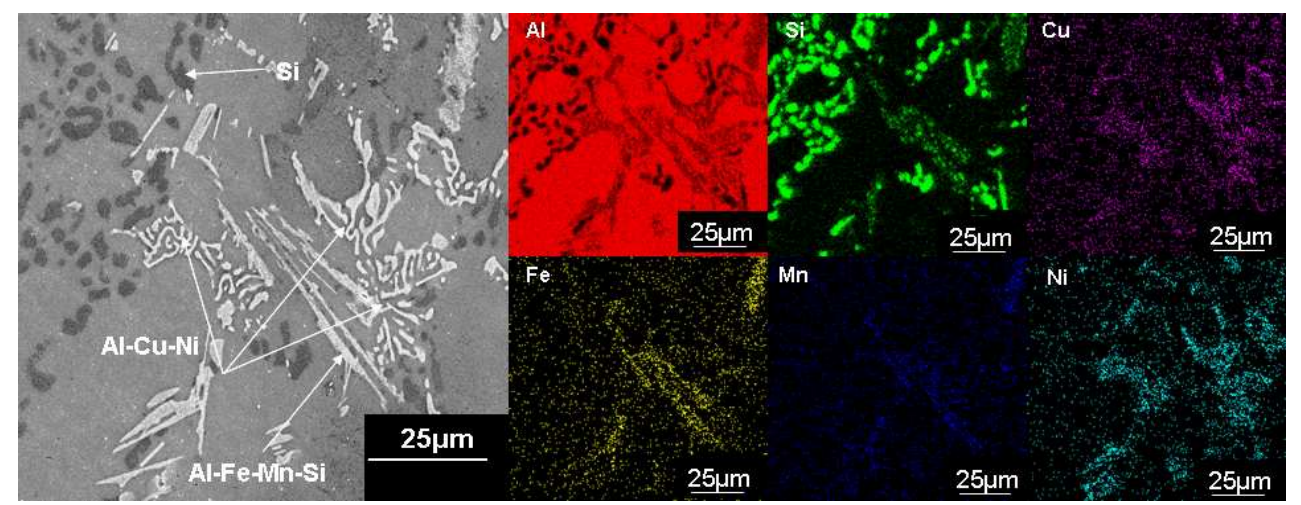

Fig. 2 SEM micrograph and elemental mapping of the A319 alloy with 1 wt. \% Ni after solution treatment for $5 \mathrm{~h}$.

\section{References.}

[1] Jack W Bray in "Properties and Selection: Non Ferrous Alloys and Special Purpose Materials" , 10 ed. (ASM International, USA) p. 165-166.

[2] W. S. Miller, L. Zhuang, J. Bottema, A. J. Wittebrood. P. D. Smet, A. Haszler, A. Vieregge, Mater. Sci. Eng 280 (2000) p. 37-49.

[3] R. S. Rana, Rajesh Purohit, and S Das, Int. J. Sci. Res. Pub 2 (2012) p. 1-7.

[4] Mohammed T. Hayajneh, Adel Mahamood Hassan, Younis Mohammad Jaradat, Jordan Univ. Sci. Technol 141 (2007) p. 1-5.

[5] J. K. Wessel in "Handbook of advanced materials, enabling new designs", 1 ed. (John Wiley \& Sons, New Jersey) p. 185-193.

[6] M. A. Moustafa, F. H. Samuel, H. W. Doty, J. Mater. Sci 38 (2003) p. 4523-4534.

[7] Kyu-Sik Kim, Si-Young Sung, Bum-Suck Han, Chang-Yeol Jung, and Kee-Ahn Lee, Metall. Mater. Int 20 (2014) p. 243-248. 